\title{
Onion (Allium cepa L.) seedling growth using humic substances
}

\author{
Crecimiento de plántulas cebolla (Allium cepa L.) aplicando sustancias húmicas
}

\author{
Marcelle Michelloti Bettoni ${ }^{1 *}$, Átila Francisco Mógor ${ }^{1}$, Jair Fernando Kogerastki ${ }^{1}$, Volnei Pauletti ${ }^{2}$
}

\begin{abstract}
Humic substances can increment plant development, promoting the growth of shoots and roots, but their use in the production of seedlings is little studied. The aim of this study was to evaluate the effect of different doses of humic substances in promoting the growth of onion seedlings of the Alfa São Francisco Ciclo VIII variety. The experimental design was completely randomized, with five replications and six treatments: control with application of water and 5 doses $\left(5,10,15,20\right.$ and $\left.25 \mathrm{~mL} \mathrm{~L}^{-1}\right)$ of humic substances containing $10 \%$ fulvic acid. The application was performed 28 days after sowing (DAS), by immersion of trays with the seedlings in the solution according to each treatment. The following characteristics were evaluated at 48 DAS (seedling transplanting time): shoot height, root length, pseudostem diameter, shoot fresh mass, shoot dry mass, root fresh mass, root dry mass, foliar area, foliar volume, root volume and root area. The use of humic substances influenced the evaluated characteristics. The greatedy growth promotion of onion seedlings occurred between the concentrations of 17 and $20 \mathrm{~mL} \mathrm{~L}^{-1}$ of humic substances in the immersion solution.
\end{abstract}

Key words: horticulture, biofertilizer, immersion solution.

\section{RESUMEN}

Las sustancias húmicas pueden favorecer el desarrollo vegetativo, promoviendo el crecimiento de la parte aérea y raíces, pero su uso en la producción de plántulas es poco estudiado. Por lo tanto, el objetivo de este trabajo fue evaluar el efecto de la aplicación de diferentes dosis de las sustancias húmicas en el desarrollo de las plántulas de cebolla 'Alfa São Francisco Ciclo VIII'. El diseño experimental fue completamente al azar, con cinco repeticiones y seis tratamientos, siendo ellos: testigo, con aplicación de agua y cinco dosis de las sustancias húmicas que contenga $10 \%$ de ácido fúlvico $(5,10,15,20$ y $25 \mathrm{~mL} \mathrm{~L}$-1). La aplicación se realizó a 28 días después de la siembra (DDS) por medio de la inmersión de las bandejas con las plántulas en la solución según cada tratamiento. A los 48 fueron evaluados: altura de la parte aérea, la longitud de las raíces, diámetro de pseudocaule, masa fresca y seca de la parte aérea, masa fresca y seca de la raíz, área y volumen de la hoja y área y volumen de la raíz. El uso de las sustancias húmicas influencian las características evaluadas. La mayoría de los efectos en el crecimiento de plántulas de cebollas fue promovido por las concentraciones entre 17 y $20 \mathrm{~mL} \mathrm{~L} \mathrm{~L}^{-1}$ de las sustancias húmicas en la solución de inmersión de plántulas de cebolla.

Palabras clave: horticultura, biofertilizante, solución de inmersión.

\section{Introduction}

In horticulture, seedling production is one of the stages of the production and is a widespread system of great importance, since the performance of the crop in the field depends on the agronomic quality of the seedlings. In the case of the onion, the seedling production process has received particular attention, largely because its seeds are of high cost and reduced size, and are very sensitive to the constant cycles of hydration-dehydration in soil
(Trigo et al., 1999). This step requires obtaining seedlings with maximum force and sanity, with appropriate development, good root system formation and better ability to adapt to the new location after transplanting (Pereira et al., 2010).

According to Costa et al. (2009) there is a need to verify in a practical way, for each species, the type of substrate or the best composition that allows obtaining vigorous plants. Bezerra et al. (2009) claim that the use of handmade substrates produced with cultural remains, depending on the

1 Universidade Federal do Paraná - Departamento de Fitotecnia e Fitossanitarismo - Rua dos Funcionários, 1540, CEP 80035050, Curitiba-PR, Brasil.

2 Universidade Federal do Paraná - Departamento de Solos e Engenharia Agrícola - Rua dos Funcionários, 1540, CEP 80035050, Curitiba-PR, Brasil.

* Correspondig author: atila.mogor@ufpr.br

Fecha de Recepción: 13 Noviembre, 2014.

Fecha de Aceptación: 24 Marzo, 2015. 
materials used in the formulation, does not always provide sufficient nutrient levels to promote the satisfactory development of the seedlings. Another reason why producers do not invest in commercial substrates is their high cost, which justifies the need to provide quality products to obtain seedlings with the lowest cost (Baldotto et al., 2009; Bernardes et al., 2011).

A cost-effective alternative is the addition of organic matter or biofertilizer as humic substances (HS) to the substrate, which provides benefits such as increasing the capacity of moisture retention and cationic exchange capacity, among others (Pereira et al., 2010). Humic substances are composed of humic acids, fulvic acids and humin from biochemical transformations of compounds of soil organic matter such as lignin, cellulose, hemicellulose, sugars and amino acids (Primo et al., 2011). Humic substances increase the capacity of moisture retention in the soil or substrate (Khaled and Fawy, 2011), assist in the transport and absorption of nutrients Chen et al., 2004; Baldotto et al., 2009) due to the formation of complexes and chelates, reducing the need for chemical fertilizer application (Zhang et al., 2013). In addition, HS have important action in the cellular metabolism of $\mathrm{N}$, increasing the level of $\mathrm{NO}_{3}^{-}$(Piccolo et al., 1993), increasing respiration and the speed of enzymatic reactions of the Krebs cycle (Nardi et al., 2007), increasing the content of chlorophyll (Baldotto et al., 2009), acting on protein synthesis (Canellas et al., 2002; Façanha et al., 2002) and active hormones such as auxin, cytokinins, gibberillins (Arancon et al., 2012), polyamines and abscisic acid (Mora et al., 2010, 2013).

HS also promote the growth of plants, through the greater development of shoot and root (Baldotto et al., 2009; Gulser et al., 2010; Ortiz et al., 2010; Bernardes et al., 2011; Daur and Bakhashwain, 2013), with an increase in the production of secondary roots (Canellas et al., 2002; Zandonadi et al., 2007; Oliveira Aguiar et al., 2009; Rosa et al., 2009). Venter et al. (1991) observed greater root length of seedlings of onion cv. Texas Grano that were obtained in seed treatment with humic substances, but there are no reports about the effects of these substances applied to onion seedlings. The objective of this study was to evaluate the effect of different doses of humic substances to promote the growth of seedlings of onion cv. Alfa São Francisco Ciclo VIII.

\section{Materials and Methods}

Onion cv. Alfa São Francisco Ciclo VIII' (Empresa Brasileira de Pesquisa AgropecuáriaEMBRAPA) seeds were sown on May 15, 2012 in polystyrene trays containing 288 cells, cut into plots of $5 \times 11$ cells, each plot consisted of 55 cells. The cells were filled with commercial substrate Plantmax ${ }^{\circledR}$ (Agroads, Brazil) and the trays were kept in a greenhouse with micro sprinkler timed irrigation with intervals of two hours. The experimental design was completely randomized with 6 treatments and 5 replicates; composed of the control with application of water, and five doses of product containing humic substances: $0,5,10,15$, 20 and $25 \mathrm{~mL} \mathrm{~L}^{-1}$. The original commercial solution had $10 \%$ fulvic acid, $90 \%$ humic substances and $\mathrm{pH} 4.0$, originating from Leonardite (Nutriplant ${ }^{\circledR}$ ), with $34.4 \% \mathrm{C} ; 3.8 \% \mathrm{H}$ and $2.3 \% \mathrm{~N}$.

The application was performed 28 days after sowing (DAS) through the immersion of trays in $2 \mathrm{~L}$ of syrup for 60 seconds. Ten plants per repetition were collected 48 DAS and the following characteristics were evaluated: shoot height (SH), root length (RL), diameter of pseudostem (DP), shoot fresh mass (SFM), shoot dry mass (SDM), root fresh mass (RFM), root dry mass (RDM), leaf area (LA), foliar volume (FV), root volume (RV) and root area (RA).

For RL evaluation we used a graduated ruler, taking the average measurement of the 3 largest roots. To obtain the LA, FV, RV and RA the samples were analyzed in the image analysis computer program WinRhizo ${ }^{\circledR}$, coupled to a Scanner LA1600. The leaves were taken separately and pressed for reading; the value obtained was multiplied by 2 , because the leaves are cylindrical. The roots were immersed in water for easy reading. The data obtained were evaluated for homogeneity of variances by the Bartlett test and subsequently subjected to regression analysis.

\section{Results and Discussion}

The maximum pseudostem diameter (DP) was obtained with the humic substance concentration of $17.1 \mathrm{~mL} \mathrm{~L}^{-1}$, with an increase of more than 10 mm compared to the control (Figure 1A).

The maximum shoot height was obtained with the concentration of $13.8 \mathrm{~mL} \mathrm{~L}^{-1}$, while root length increased linearly with increasing concentration of humic substances in the substrate (Figure 1B). 


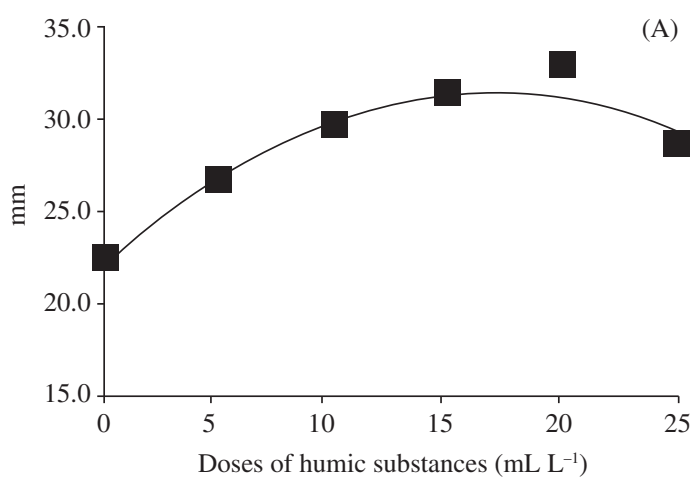

PD: $y=-0.0317 x^{2}+1.082 x+22.043 \_R^{2}=0.933 * *$

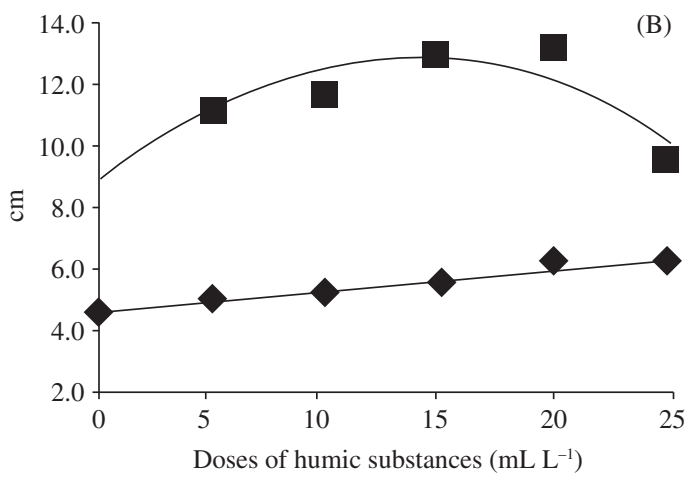

SH: $y=-0.0222 x^{2}+0.6129 x+8.5493 \_R^{2}=0.827 * *$

$R L: y=0.0617 x+4.8219+R^{2}=0.882 * *$

Figure 1. Diameter of the pseudostem (DP) (A), shoot height (SH) and root length (RL) (B) of seedlings of onion cv. Alfa São Francisco Ciclo VIII as a function of immersion in humic substances, 48 days after sowing. Curitiba, 2013.

These data reflect the effect of humic substances, probably promoted by the presence of auxin compounds, as detected by Quaggiotti et al. (2004) in tests with corn, that activate the $\mathrm{H}^{+-}$ATPase the plasmatic membrane, acidifying the apoplast and activating enzymes that act directly on the cell wall, allowing greater plasticity and leading to cell elongation.

Plant growth may also be attributed to the presence of polyamines such as spermidine, spermine and putrescine found in HS (Young and Chen, 1997), which act as regulators of plants. For Dobbss et al. (2007) the growth is attributed to alkylamides, a new class of compounds with hormonal action, producing the main root growth stimulation independently of auxin signaling (Ramírez-Chávez et al., 2004).

Both leaf area and root area increased with the increase in concentration of HS, up to 17.7 and 19.2 $\mathrm{mL} \mathrm{L}^{-1}$, respectively (Figure $2 \mathrm{~A}$ ). This increase in area was nearly $60 \%$ for both shoots and roots, corroborating the results of Atiyeh et al. (2002) formed during the breakdown of organic wastes by earthworms (vermicomposting), who obtained greater leaf area with the application of $500 \mathrm{mg} \mathrm{kg}^{-1}$ of humate. In an experiment with humic acids in corn, Zandonadi et al. (2007) also observed similar results, with increased proliferation of secondary
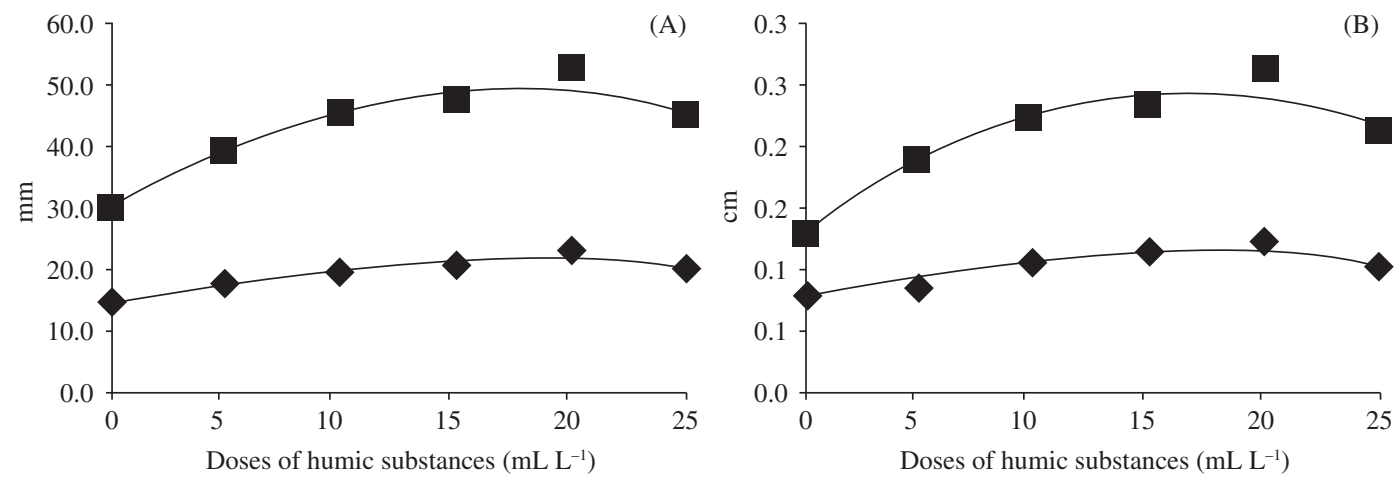

FA: $y=-0.0703 x^{2}+2.492 x+30.641 \_R^{2}=0.939 * *$
RA: $y=-0.0213 x^{2}+0.8208 x+13.932 \_R^{2}=0.913 * *$

$\mathrm{FV}: \mathrm{y}=-0.0004 \mathrm{x}^{2}+0.0149 \mathrm{x}+0.1336 \_\mathrm{R}^{2}=0.948 * *$
$\mathrm{RV}: \mathrm{y}=-0.0001 \mathrm{x}^{2}+0.0049 \mathrm{x}+0.0851 \mathrm{R}^{2}=0.777 * *$

Figure 2. Foliar area (FA), root area (RA) (A), foliar volume (FV) and root volume (RV) (B) of seedlings of onion cv. Alfa São Francisco Ciclo VIII as a function of the immersion in humic substances, 48 days after sowing. Curitiba, 2013. 
roots resulting in greater root area. This increase in surface area of the root system of onion seedlings is explained by the emergence of new roots and thin lateral roots, probably as a function of stimulus of $\mathrm{H}^{+-}$ATPase due to the presence of HS of low molecular weight.

The foliar and root volume increased as a function of the dose of humic substances (Figure 2B), with highest values at doses of 18.6 and $24.5 \mathrm{~mL}$ $\mathrm{L}^{-1}$, respectively, probably as a consequence of an increase in the area of these two fractions of plants (Figure 2A).

The volume and foliar area, as well as shoot height, were influenced by the auxin effect on enzyme expansin, responsible for cell elongation. Acidification of the cell wall caused by humic substances probably stimulated this enzyme, which justifies the increases observed by the application of these substances (Quaggiotti et al., 2004).

Root and shoot fresh mass of onions increased until the concentration of humic substances of 18.38 and $21.38 \mathrm{~mL} \mathrm{~L}^{-1}$, respectively (Figure $3 \mathrm{~A}$ ). Similarly, shoot and root dry mass increased by more than three times with the application of humic substances, but with the maximum obtained at somewhat larger doses of 18.73 and $20.06 \mathrm{~mL}$ $\mathrm{L}^{-1}$, respectively (Figure 3B), agreeing with results found by Rosa et al. (2009) in bean plants treated with humic substances.

Similar results were obtained Eyheraguibel et al. (2008), who observed positive effects of humic treatment on the shoot and root length of corn, in addition to greater fresh and dry mass, which according to these authors can be explained by possible interaction (direct or indirect) with plant growth regulators, as auxin present in the humic molecules.

All variables except root length, showed a quadratic behavior, with reductions values in dose $25 \mathrm{~mL} \mathrm{~L}^{-1}$, which could be explained by a possible cause toxic effects.

The greatest effects of application of HS occurred between the doses of 17 and $20 \mathrm{~mL} \mathrm{~L}^{-1}$, indicating this range of dose to be the most suitable for the production of onion seedlings. The application of humic substances during the production of onion seedlings, cv. Alfa São Francisco Ciclo VIII positively influenced the growth of plants.

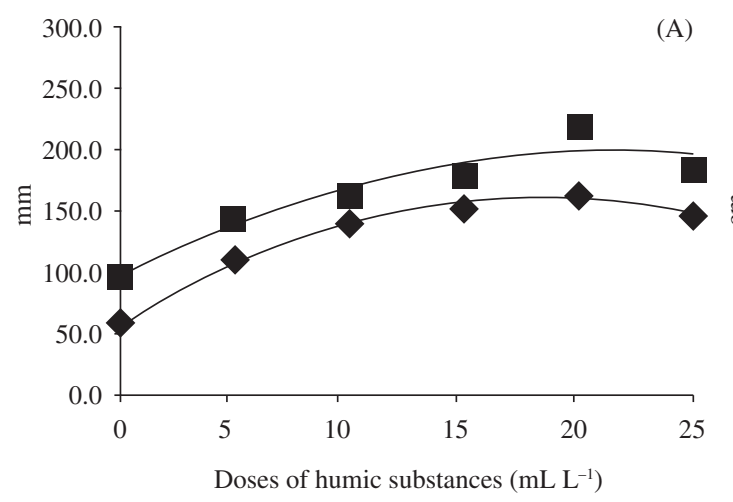

SFM: $\mathrm{y}=-0.2529 \mathrm{x}^{2}+10.813 \mathrm{x}+91.786 \_\mathrm{R}^{2}=0.855 * *$ RFM: $\mathrm{y}=-0.3243 \mathrm{x}^{2}+11.924 \mathrm{x}+55.929 \_\mathrm{R}^{2}=0.990 * *$

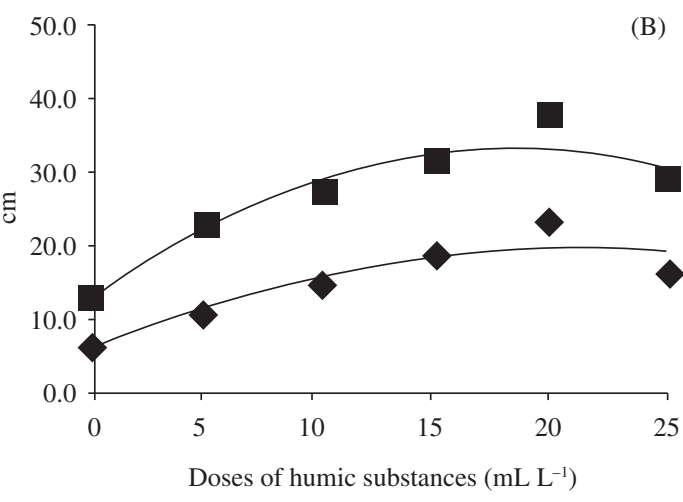

SDM: $y=-0.0645 x^{2}+2.4153 x+12.646 \_R^{2}=0.909 * *$ RDM: $y=-0.0387 x^{2}+1.553 x+4.7793 \_R^{2}=0.866 * *$

Figure 3. Shoot fresh mass (SFM), root fresh mass (RFM) (A), shoot dry mass (SDM) and root dry mass (RDM) (B) of seedlings of onion cv. Alfa São Francisco Ciclo VIII as a function of the immersion in humic substances, 48 days after sowing. Curitiba, 2013. 


\section{Literature Cited}

Arancon, N.Q.; Pant, A.; Radovich, T.; Hue, N.V.; Potter, J.K. and Converse, C.E.

2012. Seed germination and seedling growth of tomato and lettuce as affected by vermicompost water extracts (teas). HortScience, 47 (12): 1722-1728.

Atiyeh, R.M.; Lee, S.; Edwards, C.A.; Arancon, N.Q. and Metzger, J.D. 2002. The influence of humic acids derived from earthwormprocessed organic wastes on plant growth. Bioresource Technology, 84 (1): 7-14.

Baldotto, L.E.B.; Baldotto, M.A.; Giro, V.B.; Canellas, L.P.; Olivares, F.L. and Bressan-Smith, R.

2009. Desempenho do abacaxizeiro "Vitória" em resposta à aplicação de ácidos húmicos durante a aclimatação. Revista Brasileira de Ciencia do Solo, 33 (4): 979-990.

Bernardes, J.M.; Reis, J.M.R. and Rodrigues, J.F.

2011. Efeito da aplicação de substância húmica em mudas de tomateiro. Global Science and Technology, 4 (3): 92-99.

Bezerra, P.S.G.; Grangeiro, L.C.; Negreiros, M.Z. de and Medeiros, J.F. de.

2009. Utilização de bioestimulante na produção de mudas de alface. Científica, 35 (1): 46-50.

Canellas, L.P.; Olivares, F.L.; Okorokova-Façanha, A.L. and Façanha, A.R.

2002. Humic acids isolated from earthworm compost enhance root elongation, lateral root emergence, and plasma membrane H+-ATPase activity in maize roots. Plant physiology, 130 (4): 1951-1957.

Chen, Y.; Clapp, C.E. and Magen, H.

2004. Mechanisms of plant growth stimulation by humic substances: The role of organo-iron complexes. Soil Science and Plant Nutrition, 50 (7): 1089-1095.

Costa, L.M.; Andrade, J.W. de S.; Rocha, A.C. da; Souza, L., de P. and Neto, J.F.

2009. Avaliação de diferentes substratos para o cultivo de pepino (Cucumis sativus L.). Global Science and Technology, 2 (2): 21-26.

Daur, I. and Bakhashwain, A.

2013. Effect of humic acid on growth and quality of maize fodder production. Pak. Journal Botan, 45 (1): 21-25.

Dobbss, L.B.; Medici, L.O.; Peres, L.E.P.; Pino-Nunes, L.E.;

Rumjanek, V.M.; Façanha, A. R. and Canellas, L.P.

2007. Changes in root development of Arabidopsis promoted by organic matter from oxisols. Annals of Applied Biology, 151 (2): 199-211.

Eyheraguibel, B.; Silvestre, J. and Morard, P.

2008. Effects of humic substances derived from organic waste enhancement on the growth and mineral nutrition of maize. Bioresource technology, 99 (10): 4206-4212.

Façanha, A.R.; Façanha, A.L.O.; Olivares, F.L.; Guridi, F., Santos, G.D.A.; Velloso, A.C.X.; Rumianek, V.M.; Brasil, F.; Schrispsema,

J., Braz-Filho, R., De Oliveira, M.A. and Canellas, L.P.

2002. Bioatividade de ácidos húmicos: efeitos sobre o desenvolvimento radicular e sobre a bomba de prótons da membrana plasmática. Pesquisa Agropecuária Brasileira, 37 (9): 1301-1310.

Gulser, F., Sonmez, F. and Boysan, S.

2010. Effects of calcium nitrate and humic acid on pepper seedling growth under saline condition. Journal of Environmental Biology, 31 (3): 873-876.
Khaled, H. and Fawy, H.A.

2011. Effect of different levels of humic acids on the nutrient content, plant growth, and soil properties under conditions of salinity. Soil and Water Research, 6 (1): 21-29.

Mora, V.; Bacaicoa, E., Baigorri, R.; Zamarreño, A.M. and García-Mina, J.M.

2013. NO and IAA key regulators in the shoot growth promoting action of humic acid in Cucumis sativus L. Journal of Plant Growth Regulation, 33 (2): 430-439.

Mora, V.; Bacaicoa, E.; Zamarreño, A.-M.; Aguirre, E.; Garnica,

M.; Fuentes, M. and García-Mina, J.-M.

2010. Action of humic acid on promotion of cucumber shoot growth involves nitrate-related changes associated with the root-to-shoot distribution of cytokinins, polyamines and mineral nutrients. Journal of Plant Physiology, 167 (8): 633-642.

Nardi, S., Muscolo, A. and Vaccaro, S.

2007. Relationship between molecular characteristics of soil humic fractions and glycolytic pathway and krebs cycle in maize seedlings. Soil Biology and Biochemistry, 39 (12): 3138-3146.

Oliveira Aguiar, N. de; Canellas, L.P.; Dobbss, L.B.; Zandonadi,

D.B.; Olivares, F.L. and Façanha, A.R.

2009. Distribuição de massa molecular de ácidos húmicos e promoção do crescimento radicular. Revista Brasileira de Ciência do Solo, 33 (6): 1613-1623.

Ortiz, J.C.R.; Osti, C.; Jáuregui, J.A.A.; Sánchez, L.B., Goné,

J. D.J.T.; Morales, C. V. and Hernández, J.L.G.

2010. Efecto de dosis y momento de aplicación de lombricomposta en la producción de cebollita cambray (Allium cepa). Agrofaz, 10 (2): 99-106.

Pereira, P.C.; Melo, B. de; Freitas, R.S. de; Tomaz, M.A. and Freitas, C. de J.P.

2010. Mudas de tamarindeiro produzidas em diferentes níveis de matéria orgânica adicionada ao substrato. Revista Verde, 5 (3): 152-159.

Piccolo, A.; Celano, G.; Pietramellara, G.; Chimico-agrarie, D.S.; Ii, F. and Universit, V.

1993. Effects of fractions of coal-derived humic substances on seed germination and growth of seedlings (Lactuga sativa and Lycopersicum esculentum). Biology and Fertility of Soils, 16 (1): 11-15.

Primo, D.C.; Menezes, R.S.C. and Silva, T.O.

2011. Substâncias húmicas da matéria orgânica do solo: uma revisão de técnicas analíticas e estudos no nordeste brasileiro. Scientia Plena, 7: 1-13.

Quaggiotti, S.; Ruperti, B.; Pizzeghello, D.; Francioso, O., Tugnoli, V. and Nardi, S.

2004. Effect of low molecular size humic substances on nitrate uptake and expression of genes involved in nitrate transport in maize (Zea mays L.). Journal of Experimental Botany, 55 (398): 803-813.

Ramírez-Chávez, E.; López-Bucio, J.; Herrera-Estrella, L. and Molina-Torres, J.

2004. Alkamides isolated from plants promote growth and alter root development in Arabidopsis. Plant physiology, 134 (3): 1058-1068.

Rosa, C.M.D.; Castilhos, R.M.V.; Vahl, L.C.; Castilhos, D.D.; Pinto, L.F.S.; Oliveira, E.S. and Leal, O.D.A.

2009. Efeito de substâncias húmicas na cinética de absorção de potássio, crescimento de plantas e concentração de 
nutrientes em Phaseolus vulgaris L. Revista Brasileira de Ciência do Solo, 33 (4): 959-967.

Trigo, M.; Nedel, J. and Trigo, L.

1999. Condicionamento osmótico em sementes de cebola: I. efeitos sobre a germinação. Scientia Agricola, 56 (4): 1059-1067.

Venter, H.A., Furter, M., Dekker, J. and Cronje, I.J.

1991. Stimulation of seedling root growth by coal-derived sodium humate. Plant and Soil, 138 (1): 17-21.

Young, C.C. and Chen, L.F.

1997. Polyamines in humic acid and their effect on radical growth of lettuce seedlings. Plant and Soil, 195 (1): 143-149.
Zandonadi, D.B.; Canellas, L.P. and Façanha, A.R.

2007. Indolacetic and humic acids induce lateral root development through a concerted plasmalemma and tonoplast H+ pumps activation. Planta, 225 (6): 1583-1595.

Zhang, L.; Zhou, J.U.N.; Zhao, Y.G.U.I.; Zhai, Y.; Wang, K.A.I.; Alva, A.K. and Paramasivam, S.

2013. Optimal combination of chemical compound fertilizer and humic acid to improve soil and leaf properties, yield and quality of apple (Malus domestica) in the loess plateau of China. Pak. Journal Botany, 45 (4): 1315-1320. 